\title{
St. René Goupil: the patron saint of anesthesia
}

\author{
Lucas Mosienko
}

Received: 13 October 2017/Accepted: 13 October 2017/Published online: 15 December 2017

(C) Canadian Anesthesiologists' Society 2017

René Goupil (1608-1642) was a French surgeon and lay missionary who travelled with the Jesuits to New France in 1640. Despite developing an illness that rendered him deaf (and thus unable to be ordained a Jesuit), Goupil served at Saint Joseph de Sillery Mission (near Quebec City) and the nearby first Hôtel Dieu de Québec, where he cared for the sick, which included dressing wounds and performing blood letting. ${ }^{1,2}$

In 1642, on a mission to Huron territory, Goupil and his associated group of missionaries were captured by the Mohawk people. ${ }^{3}$ Goupil was brutally tortured while in captivity. Despite enduring considerable suffering, when the Mohawk community needed medical assistance, Goupil was first to help "with as much charity as he would have shown the dearest friend." ${ }^{4}$ At a point in time when he knew he was near death, Goupil asked Isaac Jogues, a fellow Jesuit missionary, to anoint him, making him a Jesuit friar. After being seen blessing a Mohawk child with the sign of the cross - misinterpreted by a Mohawk leader as a curse - Goupil was violently killed.

Goupil did not let the unfortunate events of his life define the way he treated others. He was known to be patient, compassionate, and willing to help in any capacity. Canonized in 1930, his selflessness and ability to conduct himself well in difficult times, as well as to relieve pain and

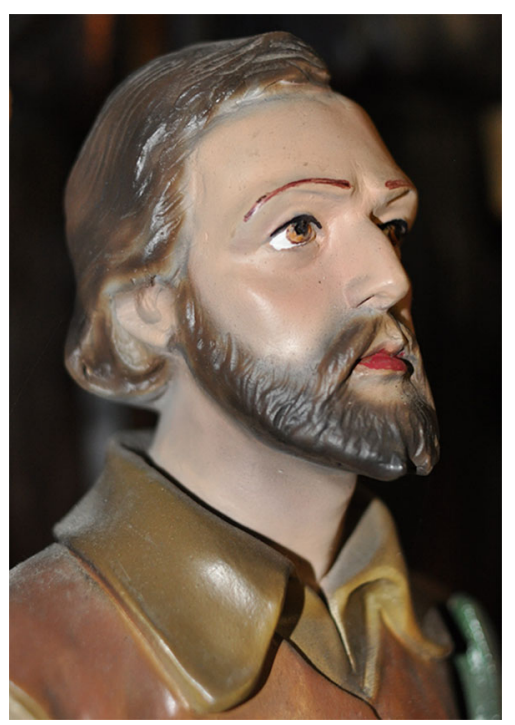

Figure A photograph of a statue of St. René Goupil, the patron saint of anesthesia, which resides among a few other small statues representing the "Canadian martyrs" located in the Église de l'Immaculée-Conception in Montreal. This church was directed by Jesuit priests from 1898 to 1999 and can still be visited. Photograph courtesy of Daniel Chartrand

suffering, were the traits noted to justify his becoming the patron saint of anesthetists in $1951 .^{5}$ 
Conflicts of interest None declared.

Editorial responsibility This submission was handled by Dr. Hilary P. Grocott, Editor-in-Chief, Canadian Journal of Anesthesia.

\section{References}

1. Canadian Martyrs Catholic Church. Lives of the Canadian Martyrs - St. Rene Goupil - written by McE Galbreath. Available from URL: http://canadianmartyrs.org/resources/ canadian-martyrs/ (accessed October 2017).
2. Dictionary of Canadian Biography. Pouliot L. Goupil, René -, University of Toronto/Université Laval. Available from URL: http://www.biographi.ca/en/bio/goupil_rene_1E.html (accessed October 2017).

3. The Arlington Catholic Herald. A patron saint for anesthesiologists - written by Thomas Craughwell - December 10, 2011. Available from URL: http://www.catholicherald.com/faith/a_patron_saint_ for_anesthesiologists/ (accessed October 2017).

4. Jogues I. Rene Goupil 1608-1642 - Isaak Jogues Narrative. Available from URL: http://www.wyandot.org/goupil.htm (accessed October 2017).

5. Quintal J. Rene Goupil: patron saint of anesthetists. AANA J 1995; 63: 191-3. 